\title{
Margaret Harkness, W. T. Stead, and the transatlantic social gospel network
}

\author{
Helena Goodwyn
}

\begin{tabular}{|c|c|}
\hline Date of deposit & 22012020 \\
\hline Document version & Author's accepted manuscript \\
\hline Access rights & $\begin{array}{l}\text { Copyright (C) } 2019 \text {, the Author. This work is made available online } \\
\text { in accordance with the publisher's policies. This is the author } \\
\text { created, accepted version manuscript following peer review and } \\
\text { may differ slightly from the final published version. }\end{array}$ \\
\hline $\begin{array}{l}\text { Citation for } \\
\text { published version }\end{array}$ & $\begin{array}{l}\text { Margaret Harkness, W. T. Stead, and the transatlantic social } \\
\text { gospel network. In F. Janssen, \& L. Robertson (Eds.), Margaret } \\
\text { Harkness and writing social engagement, 1880-1921 (pp. 182- } \\
\text { 198). (Interventions: Rethinking the Nineteenth Century). } \\
\text { Manchester University Press. }\end{array}$ \\
\hline $\begin{array}{l}\text { Link to published } \\
\text { version }\end{array}$ & https://doi.org/10.7228/manchester/9781526123503.003.0011 \\
\hline
\end{tabular}

Full metadata for this item is available in St Andrews Research

Repository at: https://research-repository.st-andrews.ac.uk/

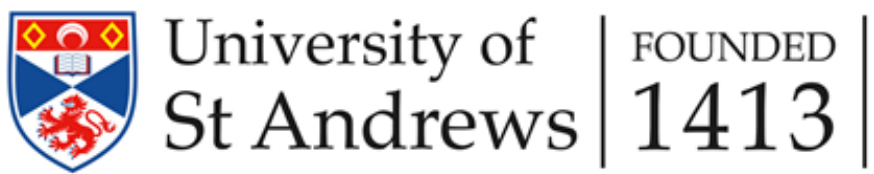




\section{Margaret Harkness, W. T. Stead and the Transatlantic Social Gospel Network}

To be a journalist in the second half of the nineteenth century was often to be caught between accusations of evangelism and commercialism. For Margaret Harkness and W. T. Stead the impulse towards wanting to reach as wide an audience as possible created a tension between their idealism and popularism that each sought to overcome by marketing their respective social-activist texts as part of a wider, transnational network of reform. This chapter, therefore, considers Harkness' 1889 novel Captain Lobe: A story of the Salvation Army, and Stead's 1894 socio-religious treatise If Christ Came to Chicago! A Plea for the Union of All Who Love in the Service of All Who Suffer, in light of each author's attempts to align themselves with a movement of greater significance than their writings could achieve on their own: the transatlantic social gospel network.

This movement has been described by Christopher H. Evans, Paul T. Phillips, Daniel T. Rodgers, and others as significant because it used the evangelising impulse of the 'gospel' to insist upon institutional reform of the 'social' at a time of 'intense, transnational traffic in reform ideas, policies, and legislative devices' (Rodgers, 1998: 3). Considering the implications of Harkness and Stead's participation in this period of Western moral and religious reevaluation, that Rodgers identifies as beginning in 1870, coinciding with, or precipitating, the Second Industrial Revolution, and ending with the Second World War, provides a context for Harkness' writings that has hitherto been missing in discussion of her influence. ${ }^{\mathrm{i}}$

Evidence of this atmosphere of moral and religious re-evaluation-or: the social gospel movement-can be found in records of public meetings; private correspondence; all manner of published texts including poetry, travel writing, and journalism; pamphlets such as The Bitter Cry of Outcast London (1883); and social reform texts such as the Salvation Army's In Darkest England and the Way Out (1890), published on both sides of the Atlantic. This chapter will go on to explore the complex interplay between emerging modern marketing methods and the 
international network of cross-referencing between writers of fiction and nonfiction texts, exemplified here by Harkness and Stead. The establishment of an international web of reciprocal references gave the authors who were positioning themselves as part of a social gospel network the authority they needed in order to establish themselves as writers of legitimate reform treatise in a marketplace saturated with similar texts.

\section{Harkness, In Darkest England and In Darkest London}

The anonymous, sensational, penny-pamphlet The Bitter Cry of Outcast London, published in October 1883, achieved mass readership as well as lively speculation as to the identity of its author. Unlike the case of James Greenwood's infamous 'Amateur Casual' pseudonym, used to excite intrigue on publication of his 'A Night in a Workhouse' series in the Pall Mall Gazette in 1866, The Bitter Cry was not published anonymously with the intention of titillation - or so said the subsequent arguments that surrounded its authorship. ${ }^{\text {ii }}$ Rather, it was published collectively, under the auspices of the London Congregationalist Union, as a critique of the awful living conditions in the areas of London it explored. In its refusal to adhere to established allegations of immorality and godlessness as explanation for the terrible poverty and other conditions of life it witnessed the pamphlet was arrestingly modern. Its emphasis upon 'systemic social reform' or 'what many social gospelers [sic] called "social salvation,", is the defining feature of what 'sets the historic social gospel of the late nineteenth and early twentieth centuries apart from other types of religious reform' (Evans, 2015: 196).

The sensation caused by The Bitter Cry of Outcast London caught the attention of the newly appointed editor-in-chief of the Pall Mall Gazette, W. T. Stead, who gave the pamphlet substantial coverage and backing, beginning with the leader 'Is it not Time?' which appeared on the $16^{\text {th }}$ October 1883 . The article asked a series of escalating rhetorical questions, designed to excite the reader into a frenzy of indignation: 
Those who have no concern about another life have all their energies at command for the amelioration of this - but what is being done? What rich man except the American Peabody leaves his fortune to rehouse the poor? How many thinkers dedicate themselves to an exhaustive study of the method of ameliorating the condition of the homeless? Where is the leader of men who will preach a new crusade against the crying evil of our times? (Stead, 1883: 1).

In the weeks and months following publication of the pamphlet, The Bitter Cry was present in some form or another in almost every issue of the Pall Mall Gazette. This, in turn, led to the pamphlet enjoying a much-increased circulation, thus sparking greater popular interest in its subject matter. Stead's manipulation of the pamphlet was critical to establishing his reputation at the Pall Mall Gazette but, more than this, it gave him an object lesson in how to repackage and repurpose material in promotion of a cause. This lesson then came into direct use when General Booth of the Salvation Army asked Stead to act as scribe, or ghost-writer, for his controversial, doctrinal text In Darkest England and the Way Out.

In the immediate aftermath of the publication of In Darkest England in 1890 Stead's involvement was suspected and used by critics of Booth and the Army to try to destabilize the validity of the salvation scheme they were proposing. In the pamphlet Salvation Syrup or, Light on Darkest England: a Reply to General Booth George William Foote revels in the knowledge that Stead wrote In Darkest England in the:

[...] manner of 'the born journalist', that is, in the fashion of the 'Modern Babylon' and the adventures of Eliza Armstrong. He contributes the descriptions, the gush, the hysterics, the sentences crowded with adjectives and adverbs. Sometimes he writes a whole chapter, unless our literary scent misleads us; sometimes he interpolates the General, and sometimes the General interpolates Stead (Foote, 1891: 9). 
Proof of Stead's penmanship of In Darkest England is not at issue here, as undoubtedly, he is its author. ${ }^{\text {iii }}$ Instead, what we are concerned with is the association of an already successful publication, coupled with uncertainty surrounding the identity of the author, being simultaneously exploited to promote and market another text.

Margaret Harkness' novel Captain Lobe: A story of the Salvation Army was originally published in 1889 by Hodder \& Stoughton under the pseudonym John Law. It was then republished as In Darkest London: Captain Lobe under the same pseudonym by the radical London publisher William Reeves with an introduction by General Booth in $1891 .{ }^{\text {iv }}$ The remarketing of Harkness' novel Captain Lobe was, on the surface, confirmation of her association with and promotion of the Salvation Army. And yet the extent to which Harkness was actually comfortable with such an association is questionable.

The clash of socialist and evangelical rhetoric is the central tension that makes Harkness' novel Captain Lobe, or, In Darkest London, an important text in any attempt to understand how the periodical press, charitable organisations, and novelists negotiated their relationships to each other in an increasingly connected world. Taking advantage of this connectivity, publishers were beginning to make use of increasingly sophisticated, yet internationally standardized marketing methods to link popular texts. The repackaging of the novel to link it directly with In Darkest England alters the reception of the narrative as more emphatically in favour of the Salvation Army and yet the text was not revised to remove some of the criticisms of both Booth's mission and his missionaries that run throughout it. From the very beginning of the novel the titular captain is presented to us in a manner that appears matter of fact but, is actually subtly undermining:

A little man, [...] slightly made, and delicate. The life he led took the strength out of him; for he felt every word that he said, and the sympathy which he showed to his fellow-men was a fire fed by self-sacrifice. He was no milk-andwater religionist, this little captain. He did not preach about hell, and then go 
home to enjoy a good meal of roast beef and plum-pudding. If he consigned a sinner to the burning pit, he gave the sinner half of his own dinner to eat on the journey, and recognised the fact that a man's soul has an intimate relationship with a man's stomach. He hated sin in the abstract; but he loved sinners, and most of all he loved his Whitechapel people (Harkness, 1891:11).

The insistent emphasis on his slightness, 'this little captain', suggests we should interrogate the apparent praise in the passage more closely. There is a tone of derision detectable in Harkness' diction which is verified by the end of the chapter where we find Lobe wondering how to persuade the young woman Patty to return to Salvation Army accommodation. Lobe ponders why Patty would prefer the freedom of a 'cheap, dirty lodging' to the Salvation Army institution with all its rules and regulations, and he is unable to understand her friend's reference to its “"dullness"” (Harkness, 1891: 12).

Harkness tells her reader, in a moment of knowing meta-humour, 'people who really believe in hell do not indulge in the morning paper, or join a circulating library' (Harkness, 1891: 13) and yet the very rebranding of her novel must be interpreted as a move towards an audience interested in, perhaps even participants in, the work of the Salvation Army. Everywhere in the novel are indications of Harkness' equivocal view on the Salvation Army: from the robotic, rote behaviour of the officers, to the assertion that 'few educated men and women' join the Army (Harkness, 1891: 33), to Lobe's deep-seated fear of Ruth becoming a slum saviour. This is perhaps a justified fear when the real good performed by the slum saviours 'nursing the sick, and feeding the hungry with [thei]r own scanty rations' leads, as Lobe admits, to an 'early death' (Harkness, 1891: 30).

And yet, just as the novel portrays the role of the salvationists as problematic, it humanizes them in their treatment of Napoleon the performer, whose dwarfism is made a spectacle of by Harkness. More significantly, for the purposes of this argument, the novel places Christ, 'were [he] on earth this morning' (Harkness, 1891: 39), in the Salvation Hall in the East 
End of London and not in the safety of the West End within the walls of the established Church of England. Such an image of Christ, amidst the gin palaces and alleyways, is the defining trope of the social gospel movement. The juxtaposition of the holy and the profane is designed to shock the reader into a renegotiation of modern life which ultimately rewards the work of the Salvation Army.

Nonetheless the novel's somewhat ambivalent attitude toward the teachings of the Salvation Army is, surprisingly, acknowledged by Booth in the preface to the 1891 edition. The effect of this concession toward the existence of an uneasy alliance actually serves to enhance the credibility of each party's position:

I am quite aware that the author of this volume, is in many respects very far from accepting our discipline, or subscribing to our theology, but to many, the witness here given will be none the less valuable on that account. So far as we are concerned we are glad to welcome this aid, to make known a little of the darkest depths of the moral social, and material abyss, into which our officers have descended in search of God's jewels "For he that is not against us is for us" [...] (Booth, 1891: i).

By drawing attention to the inconsistencies in tone and negative depictions of Salvation Army life described by Harkness in the novel Booth adds weight to its claim to verisimilitude. But, just as Harkness cannot help poking fun at the humourless and unworldly nature of the Salvation Army in the guise of the officer Captain Lobe, so too does General Booth find it difficult not to stray into the hellfire and brimstone of the Army's original purpose. To collaborate with sensational journalists like Stead and novelists like Harkness was to enter new territory for the Salvation Army, who, as little as ten years before had been solely preoccupied with the task of saving souls. 
Harold Begbie argues in his biography of Booth that in 1880: 'This impulse [to save souls] was purely evangelical; it did not become what is called humanitarian or economic till ten years later. At its beginning, The Salvation Army was a society of men and women which existed only to preach the repentance of sins' (Begbie, 1920: 434). The 'ten years later' that Begbie refers to is the year of In Darkest England's publication. Evidence that supports the idea that the Salvation Army had indeed altered its course to join the social gospel movement can be found in General Booth's letter to the Pall Mall Gazette from 1883 in which he responded to The Bitter Cry pamphlet, stating adamantly that: 'the root of the difficulty [wa]s not material, but moral' (Booth, 1883: 11).

By the time of Harkness' novel the Army had tempered its evangelism to the point that Harkness could admire their work and accept the rebranding of her novel. A letter to the Pall Mall Gazette in March 1891 clarified her pragmatic attitude to its renaming:

Whatever its faults may be, it is a true picture of the work now done by the Salvation Army. I did not christen it "In Darkest London," but its godparents could not have found a better title for a book describing what I saw with my own eyes and heard with my own ears in the East end of this metropolis. No one could have been more prejudiced against the Salvation Army than myself when I first began what the Socialists are pleased to call my "Oriental studies." "Do you ever read the Bible?" Mr Bramwell Booth once asked me. "No," I answered; "I have seen so much humbug amongst religious people that it makes me physically ill even to look at a Bible." I own that I admire the Salvation Army now, and that I watch with intense interest the object-lesson General Booth is about to give to the public. If he fails, others will build on his foundation, for it is a step in the right direction. The Salvation Army is honest and it is not snobbish: that is why I like it (Harkness: 1891, 3). 
Harkness insists upon informing the reader that the new name for her novel was not of her choosing but that her association with the Salvation Army text In Darkest England is a genuine one in spite of her conflicted relationship with Christianity. And again, just as Booth's reference to Harkness' ambivalence in the introduction to the new edition of the novel adds to its credibility, so does Harkness' public declaration of her 'prejudice' against the army, and the allusion to her research as a journalist in the East End convey further authenticity.

Elsewhere, in an earlier article entitled "“Salvation” v. Socialism: In Praise of General Booth', despite her difficult, and often antagonistic association with Stead, Harkness recounts a remonstration "with the editor of a big London paper (not a little organ that lives by such things) on the iniquity of flattering the labour leaders and turning the heads of men already too conceited':

"Well," said the editor, "I am sorry for them, poor fellows, but we must have copy. If Christ came to earth again we should send a reporter to the Last Supper." "No, you would not," I said, "for there is only one journalist in London who would discover Jesus Christ if he came again." I meant the man who is helping General Booth with his social scheme at present (Harkness, 1891: 1-2).

The man to whom Harkness refers is none other than W. T. Stead whose work on In Darkest England inspired the successful publication of If Christ Came (Stead, 1894) four years later during his first visit to the United States of America.

\section{$\underline{\text { Stead, If Christ Came and In His Steps }}$}

Stead's experience in recycling and recasting material from his articles promoting The Bitter Cry for use in In Darkest England provided him with good practice for composing a text that 
would be similarly both sensational and didactic in If Christ Came. In its own right If Christ Came caused a small sensation on both sides of the Atlantic, but like Harkness, Stead could not have predicted that his book would closely coincide with the publication of another which gained much greater popularity: Charles Sheldon's In His Steps: What Would Jesus Do?, first published in 1896. In the case of this unanticipated alliance the relationship was reversed: whereas for Harkness a nonfiction text exceeded the popularity of her fictional offering, for Stead, Sheldon's novel eclipsed his nonfiction, but still very successful book. The strong resemblance between Stead's monograph and Sheldon's novel led Stead, in publishing a second edition of If Christ Came, to advertise its relation to the social gospel movement, which Sheldon's novel was overtly a part of, on its very dust jacket. This repeats the move that William Reeves made in renaming Harkness' novel from Captain Lobe to In Darkest London enabling it to appear as a sister text to In Darkest England. Thus, on the front cover of the second British edition of his Chicago critique, Stead spliced the two titles together to form:

The Precursor of 'In His Steps.'

If Christ came to Chicago!...

What Would Jesus Do? (Stead, 1899)

It is easy to understand why Stead reissued his book on Chicago in this way when the phenomenal success of Sheldon's is considered. Whilst it is difficult to establish exactly how many copies In His Steps sold, Gregory S. Jackson refers to the novel as in all likelihood 'the best-selling novel of the nineteenth century', and states that it sold 'eight million copies' (Jackson, 2009: 158). Timothy Miller, in his biography of Sheldon, Following In His Steps, suggests that 'tens of millions' were sold 'at least' (Miller, 1987: 85-87). The general success of the novel, it is broadly agreed, is comparable only to Harriet Beecher Stowe's Uncle Tom's Cabin and the Bible. To be associated with such a phenomenon was an opportunity Stead could not pass up and so, in the English 1899 edition of his book, Stead attempted to make the influence of If Christ Came on Charles M. Sheldon's novel explicit: 
When I published my book about Chicago five years ago, I said:-

'The suggestion "If Christ came" seems to me destined to be the watchword of a revival of Civic religion, the signs of which are not lacking either in the American Republic or in the British Empire.'

The extraordinary, nay, the unprecedented sale of Mr. Sheldon's story, “In His Steps", and its related volumes - a sale which is said to have reached the phenomenal figure of a couple of millions in the first months of this year - would seem to indicate that I was not mistaken in my expectation.

The Sheldonian books, which have been so greedily bought up and so eagerly discussed, are one and all variations upon the note which I sounded in "If Christ Came to Chicago!” The only difference is that Mr. Sheldon dealt with the subject as a novelist, whereas I was compelled to confine myself to a record of the actual facts of the city's life as I found them in the year of the World's Fair.

One hundred and fifty thousand copies of my book on Chicago were sold in Britain and America, but it has been for some time out of print.

[...] "In His Steps", alike in its diagnosis of the disease and in the remedy which it prescribes, might have been written for the express purpose of popularising the teaching of "If Christ Came to Chicago" (Stead, 1899: 1).

Sheldon, eight years Stead's and three years Harkness' junior, born in 1857 in Wellsville, New York, was, like Stead and Harkness, a 'reformer', an 'idealist', 'believer' and a 'popularizer.'v Like Stead and Harkness he was the child of a clergyman. Like Stead, the literature of his youth consisted of Scott, Shakespeare and others, and, like Stead, his first chosen occupation was to write, composing stories at the age of twelve, which led him to send articles to editors of a variety of publications, before becoming a writer for the Youth's Companion magazine (Miller, 1987: 9). In later life, Sheldon turned, again like Stead, to creating compendiums: synthesized, 
simplified, texts, such as The Everyday Bible which was itself a pre-cursor to the Reader's Digest Bible (Miller, 1987: 101).

In the preface to the 1899 English edition of If Christ Came, quoted above, Stead reports that the Sheldon novel has been 'so greedily bought up' and 'so eagerly discussed'. His use of the word 'greedily' and the repetition of the adverb 'so' suggest frustration, even jealousy, at Sheldon's success with a novel that, Stead then adds, 'might have been written' to popularize Stead's own nonfiction text. It is not difficult to detect a certain peevish quality to Stead's tone here: 'I was compelled to confine myself to a record of the actual facts'. However, he does not go so far as to accuse Sheldon of plagiarism, as that charge would have created a negative association between the two texts, when a positive promotion of Sheldon's bestselling novel as somehow owing its success to Stead, was clearly to Stead's advantage. Stead's disappointment, if he felt any, that his book had been usurped in terms of mass appeal by Sheldon's novel, was assuaged by the fact that In His Steps could have been written with the 'express purpose of popularising the teaching of "If Christ Came to Chicago"" (Stead, 1899: 2).

The 'related volumes' to which Stead alludes in his 1899 preface are, it seems more than likely, the numerous 'spin-off's' Stead's book and Sheldon's novel inspired, including: Milford W. Howard's If Christ Came to Congress (1894), Isaac G. Reed Jr.'s From Heaven to New York (1894), Edward E. Hale’s If Jesus Came to Boston (1895), Olla P. Toph’s Lazarus (1895), Elizabeth Phelps Ward's The Supply at Saint Agatha's (1896), and Cortland Myers' Would Christ Belong to a Labor Union? (1900). These publications overtly announced their affiliation with the social gospel in their titles, and the rhetoric employed in them combined the same hybrid mix of evangelising and socially progressive idealism that Harkness and Stead's earlier works had used. Analysing the way in which these texts interacted, alongside the international salience of organisations like the Salvation Army, exposes not only the intimate relationship between progressive politics and religious rhetoric in the final decades of the nineteenth century, but also the surprising fluidity of Anglo-American influence during this time. 
These patterns of influence also serve to highlight the fact that, on both sides of the Atlantic, the authors and publishers of social reform texts were intent on walking a fine line between the documentation and analysis of the problems faced by modern society and the creation of exoticized, often eroticized, tales of titillation and despair that ensured sales. In chapter five of If Christ Came, 'The Scarlet Woman', Stead mentions a book entitled In Darkest Chicago. The title of this American publication again conjures immediate connections with In Darkest England and the Way Out and Morton Stanley's In Darkest Africa, published a few months earlier than In Darkest England in June 1890. Stanley's In Darkest Africa was, as the opening chapter of In Darkest England makes clear, the inspiration for its title but, also, for many of the book's tropes and semantic choices. As Seth Koven has documented in relation to other nineteenth-century social commentaries, these texts, and novels like In Darkest London, figured areas of extreme poverty 'as sites of spectacular brutality and sexual degradation' (Koven, 2004: 4) in which the working classes feature as the racialized other. The figuring of the poor as 'more like beasts than human beings' (Harkness, 1891: 245) is a common analogy, despite the tales of individual suffering that seem to work to the contrary.

Harkness and Stead both exhibit signs of being aware of the problem of finding a balance between documentation and analysis, and the divulging of sordid and brutal episodes. For Harkness a reminder that 'the scum [are no] worse than the rest' and that while the 'scum is brutal, the refined is vicious' (Harkness, 1891: 14) is enough to justify the motivation to witness or read about cruelty as a unifying feature of existence. Stead too is aware of this phenomena in the opening section of his narrative account of Chicago's social ills, as he tells his reader that Harrison Street Police Station has a 'weird fascination about it' (Stead, 1894: 4). Slums, or in the case of Stead's If Christ Came, tenement housing areas in Chicago, were 'distant outposts of empire peopled by violent and primitive races' (Koven, 2004: 4). They were places of guaranteed 'good copy' where the writer's imagination could find dramatic inspiration: 
Harrison Street Police Station is one of the nerve centres of criminal Chicago. The novelist who had at command the life story of those who, in a single week, enter this prim brick building surrounded by iron palings, would never need to draw on his imagination for incident, character, plot, romance, crime-every ingredient he could desire is there ready to hand, in the terrible realism of life (Stead, 1894: 3).

They were places too onto which the writer could map their social, political and religious aspirations, as Stead would do throughout If Christ Came, and Harkness, to a lesser degree, in In Darkest London.

The language employed by Stead throughout If Christ Came is interchangeable with that of In Darkest England and the articles in which he promoted The Bitter Cry of Outcast London. The description of Harrison Street Police Station in If Christ Came 'in the midst of darkest Chicago' mirrors the description of the 'scores' of dossers' forced to sleep on the 'stone abutments' that line the Thames Embankment:

Behind the iron bars of its underground cages are penned up night after night scores and hundreds of the most dissolute ruffians of both sexes that can be raked up in the dives of the levee (Stead, 1894: 2).

And in In Darkest England Stead pre-empts the message of If Christ Came:

As Christ came to call not the saints but sinners to repentance, so the New Message of Temporal Salvation, of salvation from pinching poverty, from rags and misery, must be offered to all. They may reject it, of course. But we who call ourselves by the name of Christ are not worthy to profess to be His disciples until we have set an open door before the least and worst of these who are now apparently imprisoned for life in a horrible dungeon of misery and despair. The responsibility for its rejection must be theirs, not ours (Stead, 1894: 29). 
The conflict between recognition of a need for public reform and a belief in the power of private redemption is ever-present in Harkness' novel and Stead's If Christ Came; the latter, in particular, emphasizes the individual's obligation to 'Be a Christ' (Stead, 1894: 432). This returns us to the tension with which the chapter opened, between idealism and popularism.

\section{Progressive Politics and Social Protestantism}

In 'Margaret Harkness and the Socialist Novel' John Goode writes:

What we don't know is whether she was a woman of consistent ideas who worked opportunistically in a series of alliances (her own image of herself), a radical feminist converted to socialism in the mid-1880s and disillusioned by it in the early 1890 s, or simply a neurotic of wide but volatile sympathies vacillating between seeing herself as a journalist in pursuit of 'cold-blooded copy' and a rejected saviour of the working class (Goode, 1982: 49).

This description of Harkness could have been applied, without much modification, to her contemporary Stead, whose campaigns such as 'The Maiden Tribute of Modern Babylon' brought him as much veneration as condemnation. Stead was aware that he was seen as 'inconsistent', and deemed it 'the most familiar of the jibes' he was attacked with as a journalist of the New school. In his treatise The United States of Europe: on the Eve of the Parliament of Peace, published in 1899, Stead acknowledged the accusation and admitted 'It is quite true that I have infinitely varied the method by which I have sought to attain the ultimate ideal that at the very beginning of my journalistic career I set myself to realize' (Stead, 1899: 59).

His 'ultimate ideal', akin to that of an ambition to be the saviour of the working class, was to become 'a prophet' promoting the 'Christian ideal of citizenship' (Stead quoted in Robertson Scott, 1952: 108-110). Or, as in his well-known article, 'Government by Journalism', 
published seven years later, to become not prophet in fact but 'ruler': 'the uncrowned king of an educated democracy' (Stead, 1886: 664). Removing the bombast from Stead's selfaggrandising rhetoric, Daniel Rodgers explains that 'the making of the Atlantic era in social politics' 'hinged on a new set of institutional connections with the industrialising nations of Europe,' and 'it required new sorts of brokers to span that connection' (Rodgers, 1998: 4). As journalists-cum-novelists-cum-international-commentators Harkness and Stead were just such brokers, regardless of whether we choose to see them as cold-blooded hacks or Good Samaritans.

During this period, as identified by Rodgers, 'between the democratic confidence of the early nineteenth century and the hubris of the late twentieth century':

[...] These were years in which city politicians in the United States could battle the pros and cons of city-owned streetcars on the basis of Glasgow's experience, [...] when certain model cities in England and Germany drew social progressives from around the world, when other nations' social politics, in short, were news (Rodgers, 1998: 4).

Writers like Stead and Harkness were, therefore, able to capitalize on the desire for texts that dealt with social reform from a British perspective. Moreover, Stead, whose political convictions would have seen Britain and America reunite, was almost uniquely placed to witness and chronicle the transition of global dominance from the UK to the U.S.A, as Americanisation grew at an unprecedented rate. ${ }^{\mathrm{vi}}$

As this chapter has sought to delineate, in this period texts like The Bitter Cry, In Darkest England and Harkness' edited collection of essays Toilers in London (1889), could be legitimately compared to American equivalents such as Jacob Riis' How the Other Half Lives (1890) and Lincoln Steffens' The Shame of the Cities (1904). As a consequence of such comparisons, and related borrowings, a web of common concerns and referents began to emerge, forming the transatlantic social gospel network. Elizabeth Stuart Phelps' novel, The Silent 
Partner (1870), in its detailing of the unpleasant working conditions of a New England textile mill, bought and reformed by a young lady of society and wealth, bore a relationship to the mid-century British social-problem novels of Benjamin Disraeli, Charles Dickens, Elizabeth Gaskell and the later novels of Harkness. Similarly, Stead's In Darkest England, If Christ Came, Harkness' Toilers in London and the American muckraking works of Lincoln Steffens, Jacob Riis, and others, were the immediate descendants of texts like The Bitter Cry of Outcast London.

The final words of Stead's 1902 study of Americanisation - The Americanisation of the World - could easily have featured in either of the texts discussed in this chapter because they are taken from the gospel of Mark: 'For what shall it profit a man, if he shall gain the whole world, and lose his own soul?' (Stead, 1902: 164). They serve as a reminder to us that, at the turn of the century, 'progressive politics was intricately entangled with social Protestantism' (Rodgers, 1998: 63). Harkness' last novel A Curate's Promise: a Story of Three Weeks, September 14-October 51917 (1921), and many of Stead's early-twentieth-century publications were designed as vehicles for promotion of this progressive social Protestantism, which scholars, mostly of American history, have referred to as the 'social gospel movement' or simply the 'social gospel.' ${ }^{\text {vii }}$ My use of it in this chapter, with reference to Harkness and Stead, contributes to its reformulation as a term of transatlantic importance. In their writings in the daily press, realist fiction, and their respective memberships in societies and federations, Harkness and Stead positioned themselves as contributors to both the social gospel and the more general movement towards international collaborative analysis and discussion of contemporary issues of import facing an increasingly globalized world. Harkness' awareness of the global reach of her fiction can be witnessed in an interview entitled 'A Slum-Story Writer' published in the Evening News and Post, following the publication of A Manchester Shirtmaker in early 1890 , where she was keen to make the point that the novel had been translated into Swedish and Russian, and that a French and German edition were to be anticipated (Harkness: 1890). 
The geographical similarity of the European-American urban cityscape allowed for comparative study, and enabled readers of the fiction of Harkness and others to easily translate the Whitechapel Road to Manhattan's Mulberry Street in their imaginations, or vice versa. The shock factor of the image conjured up by a character in Harkness' In Darkest London of Christ walking down the Whitechapel Road (Harkness, 1891: 67-68), or by Stead in If Christ Came of Christ entering a saloon in Chicago, gave impetus and legitimacy to an environment of international social reform.

Whether judged as cold-blooded copy hounds or passionate prophets Harkness and Stead engaged, throughout their careers, in the production of realist fiction, activist journalism, and critical travel writing that was imbued with the rhetoric of progressive Protestantism. ${ }^{\text {viii }}$ In doing so they contributed to the development of a transnational socio-religio-progressive forum, or as the title of this chapter suggests, a transatlantic social gospel network that flourished in the latter half of the nineteenth century and continued well into the twentieth.

Notes

'Rodgers' study Atlantic Crossings: Social Politics in a Progressive Age (London: Harvard
University Press, 1998) examines the entire period but this chapter confines its focus to the
period 1870-1912.
ii See Andrew Mearns, The Bitter Cry of Outcast London: with leading articles from the Pall
Mall Gazette of October 1883 and articles by Lord Salisbury, Joseph Chamberlain and Forster
Crozier, ed. and introduction by Anthony S. Wohl (Leicester: Leicester University Press, 1970)
for some discussion of the authorship furore.
iii For example, several sections of the first chapter of In Darkest England are taken verbatim
from Stead's very first article about The Bitter Cry entitled 'Is It Not Time?'
iv See also Matthew Beaumont's 'William Reeves and late-Victorian Radical Publishing:
Unpacking the Bellamy Library' in which Beaumont compares Reeves' publishing agenda to
the radical American publisher Charles H. Kerr's 'Pocket Library of Socialism' as another
example of the transatlantic networks of influence and equivalence that existed during this
period (Reeves, 2003: 94 ).
v These are all terms used by Sheldon's most recent biographer Timothy Miller in Following In
His Steps (Miller, 1987: xi).
vi Stead's publication in 1902 of The Americanisation of the World; or, the Trend of the
Twentieth Century - which he wrote as a result of studying the flow of American influence 
reaching back across the Atlantic — was a culmination of many years spent tapping into what Mary Nolan calls 'dense informal networks' of social reformists, in Europe, and across the Atlantic (Nolan, 2012: 38).

vii In 'American Progressivism: Transnational, Modernization, and Americanist Perspectives' Alan Lessoff writes 'Historians have long understood both the Social Gospel and its nemesis, social Darwinism, as transatlantic tendencies (Lessoff, 2012: 66). But the term 'social gospel', I would argue, is still framed as a predominantly American designation. Work continues to be done to challenge this assumption, as in: William R. Hutchison's, 'The Americanness of the Social Gospel: an Inquiry in Comparative history,' Church History, 44 (1975), 367-81, David M. Thompson's, 'The Emergence of the Nonconformist Social Gospel in England,' in Protestant Evangelicalism: Britain, Ireland, Germany, and America: Essays in Honour of W. R. Ward, ed. by Keith Robbins (Oxford: published for the Ecclesiastical History Society by B. Blackwell, 1990), pp. 258-60, Paul T. Phillips', A Kingdom on Earth: Anglo-American Social Christianity, 1880-1940, and Christopher H. Evans', 'The Social Gospel as "the Total Message of the Christian Salvation"”, Church History, 84 (2015), 196-198.

viii The term 'realist' is still the most accurate descriptor for Harkness' works of fiction despite the now famous pronouncement by Engels that $A$ City Girl was not realistic enough. 